\title{
Antimicrobial resistance and R-plasmid in Salmonella spp from swine and abattoir environments ${ }^{1}$
}

\author{
Norma S. Lázaro²*, Anita Tibana ${ }^{3}$, Dália P. Rodrigues4 ${ }^{4}$ Eliane M.F. Reis ${ }^{4}$, Bianca R. \\ Quintaes ${ }^{4}$ and Ernesto Hofer ${ }^{4}$
}

\begin{abstract}
Lázaro N.S., Tibana A., Rodrigues D.P., Reis E.M.F., Quintaes B.R. \& Hofer E. 2004. Antimicrobial resistance and R-plasmid in Salmonella spp from swine and abattoir environments. Pesquisa Veterinária Brasileira 24(2):57-60. Depto Epidemiologia e Saúde Pública, Instituto de Veterinária, UFRRJ, Seropédica, RJ 23890-000, Brazil. E-mail: nslazaro@ aol.com

Salmonella serovars isolated from swine are of particular interest not only because of the pathogenic potential for this animal species, but also due to its relevance with regard to public health. On basis of the profile of resistance to antimicrobials, 13 Salmonella strains were selected which belonged to the serovars Muenster (7), Derby (4), Typhimurium (1), and Braenderup (1). They were isolated from healthy swine as well as from the abattoir environment in the state of Rio de Janeiro. All strains of Salmonella were subjected to bacterial conjugation, and the E. coli K12 Nalr Lac $^{+} \mathrm{F}$ standard strain was used as receptor, with the purpose to verify the ability to transfer the resistance marks. Gene transfer phenomenon was detected in seven strains, and except Salmonella Typhimurium which transconjugated to $\mathrm{Sm}$, Tc and Su, the remaining ones were characterized by transferring mark Su only. By plasmidial analysis of strains used and their respective transconjugants, $63 \mathrm{~Kb}$ plasmid was found, which was probably related to $\mathrm{S}$. Typhimurium resistance.
\end{abstract}

INDEX TERMS: Salmonella, swine, antimicrobial resistance, R-plasmid.

\begin{abstract}
RESUM0.- [Resistência a antimicrobianos e plasmidios $R$ em Salmonella spp isoladas de suínos e do ambiente de abatedouro.] Sorovares de Salmonella isolados de suinos são de particular interesse não só pelo potencial patogênico para esta espécie animal, como também pela sua relevância em Saúde Pùblica. Com base no perfil de resistência aos antimicrobianos foram selecionadas 13 amostras de Salmonella pertencentes aos sorovares Muenster (7 amostras), Derby (4), Typhimurium (1) e Braenderup (1), isoladas de suinos sadios e do ambiente de abatedouro no Estado do Rio de Janeiro. As amostras foram submetidas a conjugação bacteriana, utilizando como receptora E. coli $\mathrm{K} 1255 \mathrm{Nal}^{\mathrm{r}} \mathrm{Lac}^{+} \mathrm{F}$ ', com a finalidade de verificar a capacidade da transferência de marcos de resistência. 0 fenômeno de transferência gênica foi detectado em 7 amostras
\end{abstract}

\footnotetext{
${ }^{1}$ Received on November 11, 2002.

Accepted for publication on August 20, 2003.

2 Depto Epidemiologia e Saúde Pública, Instituto de Veterinária, UFRRJ, Seropédica, RJ 23890-000, Brasil. *Author for correspondence. E-mail: nslazaro@aol.com

${ }^{3}$ Instituto de Microbiologia Prof. Paulo de Góes, UFRJ, Rio de Janeiro.

${ }^{4}$ Laboratório de Zoonoses Bacterianas, Depto Bacteriologia, IOC/ FIOCRUZ, Rio de Janeiro.
}

e, com exceção de Salmonella Typhimurium que transconjugou para Sm, Tc e Su, as demais se caracterizaram por transferir somente o marco Su. Na análise plasmidial das amostras doadoras e suas respectivas transconjugantes foi revelado um plasmídio de $63 \mathrm{~Kb}$, provavelmente relacionado com a multirresistência de S. Typhimurium.

TERMOS DE INDEXAÇÃO: Salmonella, suínos, resistência antimicrobiana, plasmidios R.

\section{INTRODUCTION}

Salmonella serovars other than those related to disease are being identified in clinically healthy swine by the time of slaughter (Costa et al. 1972, Zebral et al. 1974, Lázaro et al. 1997). This fact has implications on Public Health, in so far as a considerable number of such serovars are also isolated from outbreaks of human salmonellosis (Hofer \& Reis 1994, Lirio et al. 1998).

Its significance does not only lie on the attributes of virulence, but also on the capability of resistance to antimicrobials shown by some strains, as well as of the transfer of this feature through plasmids (Ishiguro et al. 1980, Simmons et al. 1988, Heffernan 1991).

The quick and widespread drug-resistance mediated by plasmidial genes in Salmonella isolates has been reported 
worldwide. During the past few decades, various countries have witnessed a significant increase in human isolates of multiresistant salmonellae (Holmberg et al. 1984, Carvalho \& Hofer 1989, Rivera et al. 1991, Asensi \& Hofer 1994, Ling et al.1998), as well as animal isolates (Hampton et al. 1995, Millemann et al. 1995, Alaniz et al. 1997, Izumiya et al. 2001).

Of particular interest is the fact that most plasmids acquire their resistance genes through transposons, whether from an other plasmid in the strain, from the chromosome or plasmids carried by other bacterial strains which are present in the host (Threlfall \& Frost 1990). In the light of this, research was carried out which concentrated essentially on $R$ factors of Salmonella, by means of conjugation tests (Timoney 1978, Vinhas \& Almeida 1984, Simmons et al. 1988, Sant'Ana et al. 1995).

In view of the complexity of the factors associated with the dissemination of resistant Salmonella strains, this paper has the purpose of assessing the capability to transfer marks of resistance to antimicrobials by means of bacterial conjugation as well as by analysis of the plasmidial profile of Salmonella isolated from clinically healthy swine, and also originating from the environment where these animals were slaughtered, in the state of Rio de Janeiro.

\section{MATERIALS AND METHODS}

For the conjugation experiments 7 samples were selected belonging to serovar Muenster; 4 samples of serovar Derby, one belonging to serovar Typhimurium, and one to serovar Braenderup. These were isolated from swine and the abattoir environment; they were resistant and/or multiresistant to sulphonamide (Su), streptomycin (Sm) and tetracycline (Tc) (Table 1).

Conjugation experiments. For the determination of $\mathrm{R}$ factors in the samples under study, the methodology used was the one described by Dias \& Hofer (1985). Conjugation was performed using

Table 1. Profile of resistance of strains utilized as donors on conjugation tests

\begin{tabular}{cccc}
\hline $\begin{array}{c}\text { Strains } \\
n \text { o }\end{array}$ & Sourcea & Serovar & $\begin{array}{c}\text { Resistance } \\
\text { profileb }\end{array}$ \\
\hline 1 & MES1 & $\begin{array}{c}\text { Braenderup } \\
\text { Muenster }\end{array}$ & $\begin{array}{c}\text { Sm, Tc, Su } \\
\text { Su }\end{array}$ \\
6 & MES4 & Muenster & Sm \\
8 & MES27 & Muenster & Su, Sm \\
22 & Ton61 & Muenster & Sm \\
$24 b$ & ING65 & Muenster & Sm \\
36 & ING66 & Muenster & Sm \\
71 & Ton98 & Derby & Sm, Tc, Su \\
72 & Ton99 & Derby & Sm, Tc, Su \\
$73 c$ & Ton99 & Muenster & Sm \\
76 & ET8 & Typhimurium & Sm, Tc, Su \\
$81 b$ & ST9 & Derby & Sm, Tc, Su \\
90 & ST9 & Derby & Tc, Su
\end{tabular}

aspecimen corresponding to animal no Ex.: MES4 = swine 4 mesenteric lymph node; $M E S=$ mesenteric lymph node; ING= inguinal lymph node; Ton = tonsil; $T E=$ scalding tank; $E T=$ evisceration table. For the environmental samples the number follows the origin corresponding to the order of collection (visit) , e.g. ET8 $=$ 8th visit.

${ }^{\mathrm{b}} \mathrm{Sm}=$ streptomycin; $\mathrm{Su}=$ sulfonamide; $\mathrm{Tc}=$ tetracycline. as recipient Escherichia coli $\mathrm{K} 1255, \mathrm{~F}^{-} \mathrm{Lac}^{+} \mathrm{Nal}^{\mathrm{r}}$, susceptible to all drugs except nalidix acid. Transconjugants were seleted on MacConkey agar (Oxoid) containing the antimicrobials to which the standard strain was originally sensitive. The resistance patterns of transconjugant strains was confirmed through the disc diffusion method according to NCCLS (1998), and considering the original profile of the corresponding donor colony.

Plasmidial analysis. The analysis of the plasmidial contents regarding the original strains and their respective transconjugants was performed by the alkaline lysis method of Birnboim \& Doly (1979), modified by Sambrok et al. (1989). The plasmidial DNAs of E. coli V 517 and 29R861 were included as molecular weight controls.

\section{RESULTS}

Table 2 shows the conjugation positivity in seven $(53.84 \%$ out of the 13 donor strains, which evidences the total transference of model Su, Tc, Sm on S. Typhimurium and partial transfer of mark Su in regard to serovars Derby and Muenster.

Table 2. Degree of resistance transfer marks to E. coli LR1 (K12 55) by Salmonella spp strains

\begin{tabular}{|c|c|c|c|c|c|}
\hline $\begin{array}{l}\text { Serovar } \\
\quad \mathrm{n}^{\circ}\end{array}$ & Strains & $\begin{array}{c}\text { Resistance } \\
\text { profile }^{a}\end{array}$ & $\begin{array}{c}\text { Transconjugants } \\
\text { (seletive drugs) }\end{array}$ & $\begin{array}{l}\text { Transfer } \\
\text { degree }\end{array}$ & $\begin{array}{c}\text { Transferred } \\
\text { Marks }\end{array}$ \\
\hline Muenster & 2 & Su & T2 Su x LR1 & $10^{-1}$ & $\mathrm{Su}^{\mathrm{R}}$ \\
\hline Muenster & 8 & $\mathrm{Sm}, \mathrm{Su}$ & T8 Su x LR1 & $10^{-1}$ & $\mathrm{Su}^{\mathrm{R}}$ \\
\hline Derby & 71 & $\mathrm{Sm}, \mathrm{Tc}, \mathrm{Su}$ & T71 Su x LR1 & $10^{-1}$ & $\mathrm{Su}^{\mathrm{R}}$ \\
\hline Derby & 72 & $\mathrm{Sm}, \mathrm{Tc}, \mathrm{Su}$ & T72 Su x LR1 & $10^{-1}$ & $\mathrm{Su}^{\mathrm{R}}$ \\
\hline Typhimurium & 76 & $\mathrm{Sm}, \mathrm{Tc}, \mathrm{Su}$ & T76 Sm x LR1 & $10^{0}$ & $\mathrm{Sm}^{\mathrm{R}}, \mathrm{Tc}^{\mathrm{R}}, \mathrm{Su}^{\mathrm{R}}$ \\
\hline Typhimurium & 76 & $\mathrm{Sm}, \mathrm{Tc}, \mathrm{Su}$ & T76 TC $x$ LR1 & $10^{-2}$ & $\mathrm{Sm}^{\mathrm{R}}, \mathrm{Tc}^{\mathrm{R}}, \mathrm{Su}^{\mathrm{R}}$ \\
\hline Typhimurium & 76 & $\mathrm{Sm}, \mathrm{Tc}, \mathrm{Su}$ & T76 Su x LR1 & $10^{-2}$ & $\mathrm{Sm}^{\mathrm{R}}, \mathrm{Tc}^{\mathrm{R}}, \mathrm{Su}^{\mathrm{R}}$ \\
\hline Derby & $81 b$ & $\mathrm{Sm}, \mathrm{Tc}, \mathrm{Su}$ & T81b Su x LR1 & $10^{-1}$ & $\mathrm{Su}^{\mathrm{R}}$ \\
\hline Derby & 90 & Tc, Su & T90 Su x LR1 & $10^{-1}$ & $\mathrm{Su}^{\mathrm{R}}$ \\
\hline
\end{tabular}

$\overline{\text { a Su}=\text { Sulfonamide, }} \mathrm{Tc}=$ Tetracyclin, $\mathrm{Sm}=$ Streptomycin.

Regarding the transfer degree determined in salmonellae by view of the growth of transconjugant samples in dilutions $10^{\circ}$, $10^{-1}$, and $10^{-2}$, it was found that from the seven transconjugants, the isolation of transconjugating up to dilution $10^{-2}$ was obtained only with $\mathrm{S}$. Typhimurium; the others were characterized by reaching up to dilution $10^{-1}$.

The antimicrobial susceptibility tests confirmed the transfer of resistance marks in all of the transconjugant strains.

In Table 3 are listed plasmids transferred by the conjugation process between Salmonella (donor) and (receptor) E. coli K12 55 (LR1). Despite the donor serovars Muenster and Derby, which showed resistance transfer to mark Su for E. coli, the analysis of plasmidial DNA in transconjugant samples did not reveal plasmids which were evidenced in the donor samples.

Regarding S. Typhimurium (strain no. 76), marks Tc, Sm, and Su were transferred, and the analysis of transconjugants (Fig. 1) revealed the presence of plasmids showing approximate sizes (Kb) of 63-3.75 and 3.45 Kb for transconjugant Sm (T76Sm x LR1), and only the $63 \mathrm{~Kb}$ plasmid on transconjugants Tc and Su (T76\&C $\times$ LR1, and T76Su $\times$ LR1). It is noteworthy that the antimicrobial susceptibility test in order to confirm transfer of $R$ factors revealed simultaneous resistance to marks Sm, Tc, and $\mathrm{Su}$ in the three transconjugants resulting from S. Typhimurium. 
Table 3. Antibiotic-resistance and plasmids $\mathrm{R}$ transferred via conjugation between Salmonella (donor) and E. coli, K12 $55 \mathrm{Nal}^{r} \mathrm{Lac}^{+} \mathrm{F}$ (receptor)

\begin{tabular}{|c|c|c|c|c|c|c|}
\hline \multicolumn{4}{|c|}{ Donor } & \multicolumn{3}{|c|}{ Receptor } \\
\hline Strains & Serovar & $\begin{array}{c}\text { Resistance } \\
\text { marks }\end{array}$ & $\begin{array}{c}\text { Plasmíds } \\
\text { (Kb) }\end{array}$ & Transconjugants & $\begin{array}{c}\text { Transferred } \\
\text { marks }^{a}\end{array}$ & $\begin{array}{c}\text { Transferred } \\
\text { plasmids (Kb) }\end{array}$ \\
\hline 2 & Muenster & Su & 7,95 & T2Su x LR1 & Su & - \\
\hline 8 & Muenster & $\mathrm{Sm}, \mathrm{Su}$ & $\begin{array}{ll}7,95- & 5,55 \\
-3,15 & 2,85\end{array}$ & T8Su x LR1 & Su & - \\
\hline 71 & Derby & $\mathrm{Sm}, \mathrm{Tc}, \mathrm{Su}$ & $5,4-10,8$ & T71Su x LR1 & Su & - \\
\hline 72 & Derby & $\mathrm{Sm}, \mathrm{Tc}, \mathrm{Su}$ & $5,4-10,8$ & T72Sux LR1 & Su & - \\
\hline 76 & Typhimurium & Sm, Tc, Su & $63-3,75-3,45$ & $\begin{array}{l}\text { T76Sm } \times \text { LR1 } \\
\text { T76Tc } \times \text { LR1 } \\
\text { T76Su } \times \text { LR1 }\end{array}$ & $\begin{array}{l}\text { Sm, Tc, Su } \\
\mathrm{Sm}, \mathrm{Tc}, \mathrm{Su} \\
\mathrm{Sm}, \mathrm{Tc}, \mathrm{Su}\end{array}$ & $\begin{array}{c}63-3,75-3,45 \\
63 \\
63\end{array}$ \\
\hline $81 b$ & Derby & $\mathrm{Sm}, \mathrm{Tc}, \mathrm{Su}$ & Não determinado & T81bSu x LR1 & $\mathrm{Su}$ & - \\
\hline 90 & Derby & Tc, Su & Não determinado & T90Su x LR1 & Su & - \\
\hline
\end{tabular}

aSu= Sulfonamide, $\mathrm{Tc}=$ Tetracycline, $\mathrm{Sm}=$ Streptomycin.

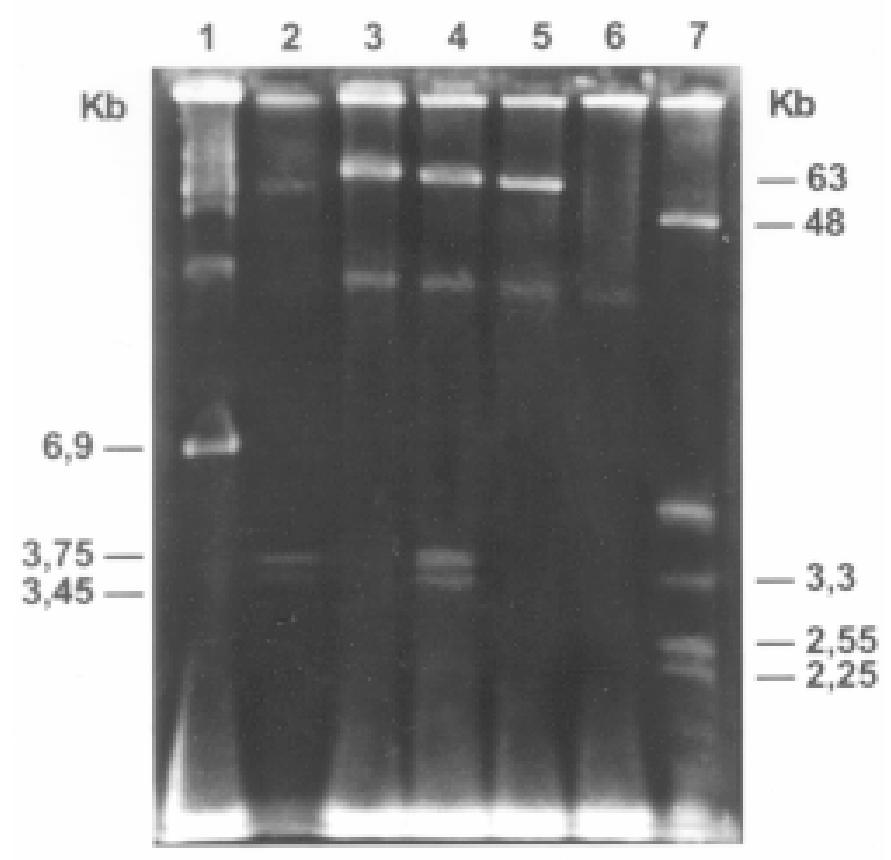

Fig. 1. Plasmid profile of resistant Salmonella Typhimurium and transconjugant lines: 1-E. coli 39R861; 2-S. Typhimurium; 3,4 and 5-transconjugants Su, Sm and Tc; 6-E coli. K 1255; 7-E. coli V517.

\section{DISCUSSION}

The information contained in the literature points out the transfer of genes among bacteria by means of conjugation, in varied environments as well as in the intestinal tracts of humans and animals (Smith 1969).

Although laboratorial experiments do not exactly reproduce - even under simulated conditions - the complexity existing in transfer processes occurring in vivo, they may constitute an important tool for making such inferences.

The negative result in the conjugation of the six Salmonella Muenster strains, as well as the absence of transconjugants for marks Sm in S. Muenster (no. 8), and Sm, Tc in S. Derby, may be related to one of the following features: the genic-chromosomic feature of these determinants; the non-existence of the transfer factor; the interference of nalidixic acid with selective plates for transconjugants; the inability of plasmid reception of the standard strain used (Barbour 1967); or even plasmid loss during handling of the samples.

The hypothesis is also admitted that these strains carry thermo-sensitive plasmids $\mathrm{R}$ encoding a resistance to $\mathrm{Tc}$ and $\mathrm{Sm}$, which are effectively transferred at $25^{\circ} \mathrm{C}$. Factors related to resistance to tetracycline seem to be effectively transferred outside the body, thereby decreasing transfer at $37^{\circ} \mathrm{C}$ (Timoney 1978). This may account for the difficulty of in vivo transfer on the part of plasmids bearing resistance of animal origin into the flora residing in man's intestine (Smith 1969). A wide distribution of thermo-sensitive plasmid in salmonellae isolated from swine was noted by Ishiguro et al. (1980) in Japan.

Analyzing Table 3 it was found that only S. Typhimurium was capable of transferring R-plasmid to E. coli . The close association between marks Su, Tc, Sm, along with the finding of simultaneous transfer to S. typhimurium transconjugants, suggests that such genic expression may be determined by the same plasmid (63 $\mathrm{Kb})$, although there have been detected two additional plasmids (3.75 and $3.45 \mathrm{~Kb}$ ) on transconjugant Sm of S. Typhimurium (T76Sm x LR1). This feature is found in the literature in so far a non-conjugating plasmid may be transferred to a receptor cell by cooperative action of a conjugative plasmid when they are present in the same cell. With regard to plasmids with relatively high molecular weights and encoding resistance to antimicrobials, in Salmonella Typhimurium these appears to exist a $40 \mathrm{~Kb}$ plasmid associated to resistance to amoxicilin, streptomycin, tetracycline, chloranphenicol, and sulfametoxazoltrimetroprin (Hansen et al. 1964), and another $80 \mathrm{~Kb}$ plasmid encoding resistance to marks Ap, Sm, Su, Tc (Hampton et al. 1995).

As to the absence of plasmids in transconjugants of $S$. Muenster and S. Derby, the hypothesis can scarcely be admitted that the determinant of resistance to mark Su is encoded by a large plasmid, which has not been demonstrated through the methodology employed. For this purpose, various methods and 
procedures were set forth, the outstanding being the one developed by Kado \& Liu (1981), which is the most convenient for extraction in view of plasmids with high molecular weight. Another explanation for this phenomenon could be the outcome of integration of the resistance-plasmid in the receptor's chromosome (Madigan et al. 1997); or, still, because of the poor stability during the storage period between tests.

The ease of in vitro transfer has led to the conclusion that similar pattern of resistance to antibiotics in different intestinal bacteria are mediated by the same resistance plasmid (R factor) and has the same origin (Cherubin 1981). In contrast, Avril et al. (1977) have shown that the same resistance pattern is expressed by different episomes, and in the same way in different Salmonella serovars. Whenever a Salmonella bearer is being treated with antibiotics and the microorganism develops a multi-resistance, similar resistance pattern may be found in the patient's intestinal flora (Aserkoff \& Bennett 1969).

The genic transfer phenomenon observed in the samples which are the object of our study emphasizes the relevance of those factors in propagating resistant bacteria in different ecological niches, besides the progressive limitations in the therapeutics using antimicrobials mostly when the level of resistance to isolates is unknown.

\section{REFERENCES}

Alaniz R.O., Ibarra M.L.R., Barbosa B.T.R. \& Morales A.L.J. 1997. Resistencia a antimicrobianos de cepas de Salmonella aisladas de fuentes animales. Vet. Méx. 28:215-220.

Asensi M.D. \& Hofer E. 1994. Serovars and multiple drug resistant Salmonella sp. isolated from children in Rio de Janeiro, Brazil. Revta Microbiol. 25:149-153.

Aserkoff B. \& Bennett J.V. 1969. Effect of antibiotic therapy in acute salmonellosis on the fecal excretion of salmonellae. New England J. Med. 281:636-640.

Avril J.L., Dabernat H.J., Gerbaud G.R., Horodiniceanu T., Lambert-Zechovsky N., LeMinor S., Mendez B \& Chabbert Y.A. 1977. Groups d'incompatibilité des plasmides $R$ chez les souches de Salmonella epidémiques. Ann. Microbiol. 128B:165-175.

Barbour S.D. 1967. Effect of nalidixic acid on conjugational transfer and expression of epissomal Lac genes in Escherichia coli K12. J. Mol. Biol. 27:373-376

Birnboim H.C. \& Doly J. 1979. A rapid alkaline extraction procedure for screening recombinant plasmid DNA. Nucleic Acids Res. 7:1513-1523.

Carvalho C.L. \& Hofer E. 1989. Antimicrobial resistance among Salmonella serovars isolated from different sources in Brazil during 1978-1983. Antonie van Leeuwenhoek J. Microbiol. Serology 35:349-359.

Cherubin C.E. 1981. Antibiotic resistance of Salmonella in Europe and the United States. Rev. Infect. Dis. 3:1105-1126.

Costa G.A., Hofer E., Costa M.D.M., Silva J.A.R., Santos J.V. \& Doria J.D. 1972. Isolation of Salmonella from pigs lymph nodes slaughtered at the abattoir of Salvador, Bahia. Mem. Inst. Oswaldo Cruz 70:417-431.

Dias J.C.A.R. \& Hofer E. 1985. Bactérias Gram negativas resistentes a antimicrobianos em alimentos. Mem. Inst. Oswaldo Cruz 80:411-421.

Hampton M.D., Threlfall E.J., Frost J.A., Ward L.R. \& Rowe B. 1995. Salmonella typhimurium DT 193: differentiation of an epidemic phage type by antibiogram, plasmid profile, plasmid fingerprint and Salmonella plasmid virulence (spv) gene probe. J. Appl. Bacteriol. 78:402-408.

Hansen M.S., Rogers M.S., Emge S. \& Jacobs N.J. 1964. Incidence of Salmonella in hog colors as affected by handing pratices prior to slaughter. J. Am. Vet. Med. Assoc. 145:139-140.
Heffernan H.M. 1991. Antibiotic resistance among salmonbella from human and other sources in the New Zealand. Epidemiol. Infect. 106:17-23.

Hofer E. \& Reis E.M.F. 1994. Salmonella serovars in food poisoning episodes recorded in Brazil from 1982 to 1991. Revta Inst. Med. Trop. 36:7-9.

Holmberg S.D., Wachsmuth I.K., Hickman-Brenner F.W. \& Cohen M.L. 1984. Comparison of plasmid profile analysis, phage typing, and antimicrobal susceptibility testing in characterizing Salmonella typhimurium isolates from outbreaks. J. Clin. Microbiol. 19:100-104.

Ishiguro N., Goto J. \& Sato G. 1980. Genetical relationship between R plasmids derived from Salmonella and Escherichia coli obtained from a pig farm, and its epidemiological significance. J. Hyg. Camb. 84:365379.

Izumiya H., Terajima J., Matsushita S., Tamura K. \& Watanabe H. 2001. Characterization of multidrug-resistant Salmonella enterica serovar Typhimurium isolated in Japan. J. Clin. Microbiol. 39:2700-2703.

Kado C.I. \& Liu S.T. 1981. Rapid procedure for detection and isolation of large and small plasmids. J. Bacteriol. 145:1365-1373.

Lázaro N.S., Tibana A. \& Hofer E. 1997. Salmonella spp. in healthy swine and in abbatoir environments in Brazil. J. Food Prot. 60:1029-1033.

Ling J.M., Koo I.C., Kam K.M. \& Cheng A.F. 1998. Antimicrobial susceptibilities and molecular epidemiology of Salmonella enterica serotype Enteritidis strains isolated in Hong Kong from 1986 to 1996. J. Clin. Microbiol. 36:1693-1699.

Lírio V.S., Silva E.A. \& Stefani S. 1998. Freqüência de 17 sorotipos de Salmonella isolados de alimentos. Revta Hig. Alimentar 12:36-42.

Madigan M.T., Martinko J.M. \& Parker J. 1997. Microbial genetics, p. 305356. In: Brock T.D., Madigan M.T., Martinko J.M. \& Parker J. (ed.) Biology of Microrganisms. $8^{\text {th }}$ ed. Prentice-Hall Inc., New Jersey.

Millemann Y., Lesage M.C., Chaslus-Dancla E. \& Lafont J.P. 1995. Value of plasmid profiling, ribotyping, and detection of IS200 for tracing avian isolates of Salmonella typhimurium and S. enteritidis. J. Clin. Microbiol. 33:173-179.

National Commitee for Clinical Laboratory Standards (NCCLS) 1998. Performance Standards for Antimicrobial Disk Susceptibility Tests 18:182.

Rivera M.J., Rivera N., Castillo M., Rubio M.C. \& Gómes-Lus R. 1991. Molecular and epidemiological study of Salmonella clinical isolates. J. Clin. Microbiol. 29:927-932.

Sambrook J., Fritsch E.F. \& Maniatis T. 1989. Molecular cloning: a laboratory manual. $2^{\text {nd }}$ ed. Cold Spring Harbor Laboratory, Cold Spring Harbor, NY, p. $125-128$.

Sant'Ana Y.X., Cassali G.D., Barbosa A.J.A., Zucchi T.M.A.D. \& ChartoneSouza E. 1995. Salmonella typhimurium plasmids simultaneously coding for tetracycline resistance, colicin production and pathogenicity. Revta Microbiol., São Paulo, 26:239-245.

Simmons K.W., Wooley R.E.\& Brown J. 1988. Comparison of virulence factors and $R$ plasmids of Salmonella spp. isolated from healthy and ill swine. Appl. Environ. Microbiol. 54:760-767.

Smith H.W. 1969. Transfer of antibiotic resistance from animal and human strains of Escherichia coli to resident E.coli in the alimentary tract of man. Lancet 1:1174-1176.

Threlfall E.J. \& Frost J.A. 1990. A Review - The identification, typing and fingerprinting of Salmonella: laboratory aspects and epidemiological applications. J. Appl. Bacteriol. 68:5-16.

Timoney J.F. 1978. The epidemiology and genetics of antibiotic resistance of Salmonella typhimurium isolated from diseased animals in New York. J. Infect. Dis. 137:67-73.

Vinhas S.A. \& Almeida D.F. 1984. Plasmid mediated antibiotic resistance and colicinogeny among Salmonella in Rio de Janeiro, Brazil. Anais Acad. Bras. Ciênc. 56:319-322.

Zebral A.A., Freitas C.A. \& Hofer E. 1974. The occurrence of Salmonella in lymphnodes of seemingly normal swine slaughtered at abattoir of Santa Cruz, Rio de Janeiro, GB. Mem. Inst. Oswaldo Cruz 62:223-236. 